\title{
PERAN BADAN NASIONAL PENANGGULANGAN TERORISME DALAM PEMBERANTASAN TERORISME DI INDONESIA
}

\author{
Muhammad Zulfikar' ${ }^{1}$ \& Aminah² \\ 1Fakultas Hukum, Universitas Bosowa \\ 2Fakultas Hukum, Universitas Diponegoro \\ muhfhy@gmail.com
}

\begin{abstract}
Terrorism is a crime or a crime of extraordinary importance to the world today especially in Indonesia. Recent terrorism has ideological, historical and political interconnectedness and is part of strategic environmental dynamics in the global and regional landscape. Even though the ACTS of terrorism that have occurred in many areas in recent years have been mostly by indonesians, and few actors on the outside. This study USES the normative yuridis research method by reviewing data sources from legal literature and literature studies. This study aims to learn about the role of BNPT and those in authority on terrorism and society, Indonesia's existing community organizations, and effectively addressing terrorism are needed to actively participate in counterterrorism activities. That is to look at the contemporary developments, BNPT continues to promote various elements of the nation to together against radicalism, encouraging counter radicalisation, continue to synergize with other government institutions as well as various media to unite and equate Perceptions in the face of these threat. The role of the media in combating terrorism is not effective enough to balance and purify the mass media from understanding radicalism, the synergity of roles with various parties is also indispensable. Therefore, it is needed the role of community, community organization, especially the district head, political figure, and scholars of islam in each region actively participated in the eradication of terrorism activities in Indonesia.
\end{abstract}

\section{Keywords: Terrorism; Eradication; The Role of The BNPT.}

\begin{abstract}
ABSTRAK
Terorisme merupakan suatu tindak pidana atau kejahatan luar biasa yang menjadi perhatian dunia sekarang ini terutama di Indonesia. Terorisme yang terjadi akhir-akhir ini memiliki keterkaitan ideologis, sejarah dan politis serta merupakan bagian dari dinamika lingkungan strategis pada tataran global dan regional. Kendatipun aksi terorisme yang terjadi di berbagai daerah dalam beberapa tahun terakhir ini kebanyakan dilakukan oleh orang Indonesia dan hanya sedikit aktor-aktor dari luar. Penelitian ini mengunakan metode penelitian yuridis normatif dengan mengkaji sumber data dari literatur hukum dan kajian kepustakaan. Penelitian ini bertujuan mengetahui tentang peran BNPT dan pihak-pihak yang berwenang dalam pemberantasan terorisme serta peran masyarakat, organisasi masyarakat yang ada di Indonesia dalam upaya menangani terorisme. Yaitu mencermati perkembangan kekinian, BNPT terus menggalang berbagai elemen bangsa untuk bersama melawan radikalisme, menggalakkan kontra radikalisasi, terus bersinergi dengan lembaga pemerintah lainnya serta berbagai media untuk menyatukan dan menyamakan persepsi dalam menghadapi ancaman tersebut. Adapun Peran dari media dalam pemberantasan terorisme tidak cukup efektif untuk menyeimbangkan dan memurnikan media massa dari paham radikalisme, sinergitas peran dengan berbagai pihak juga sangat diperlukan. Olehnya diperlukan peran masyarakat, organisasi masyarakat, khususnya Kepala Daerah, tokoh politik, dan para ulama yang ada di setiap daerah secara aktif ikut berpartisipasi dalam kegiatan pemberantasan terorisme di Indonesia.
\end{abstract}

Kata Kunci: Terorisme; Pemberantasan; Peran BNPT. 
Jurnal Pembangunan Hukum Indonesia

Volume 2, Nomor 1, Tahun 2020
Program Studi Magister Ilmu Hukum Fakultas Hukum Universitas Diponegoro

\section{A. PENDAHULUAN}

Indonesia memang selama ini menjadi langganan teror, kita bisa melihat kejadian yang nyata yaitu di Surabaya bulan Mei 2018 yang lalu dan juga kenapa setelah ada kejadian bom bunuh diri barulah pihak yang berwenang baru mengatakan siaga, melihat keadaan ini sangatlah memprihatinkan maka sudah semestinya pemerintah memprioritaskan hal seperti ini. Mengingat yang menjadi korban kebanyakan adalah masyarakat sipil.

Terorisme merupakan suatu tindak pidana atau kejahatan luar biasa yang menjadi perhatian dunia sekarang ini terutama di Indonesia. Terorisme yang terjadi di Indonesia akhir-akhir ini memiliki keterkaitan ideologis, sejarah dan politis serta merupakan bagian dari dinamika lingkungan strategis pada tataran global dan regional. Kendatipun aksi terorisme yang terjadi di berbagai daerah dalam beberapa tahun terakhir ini kebanyakan dilakukan oleh orang Indonesia dan hanya sedikit aktor-aktor dari luar.

"Namun tidak dapat dibantah bahwa aksi terorisme saat ini merupakan suatu gabungan antara pelaku domestik dengan mereka yang memiliki jejaring trans-nasional" (Hikam, 2016).

Sebagai konsekuensi dari ketidaksepakatan tentang terorisme dalam konflik bersenjata, negara sejauh ini tidak dapat memberikan definisi umum tentang seluruh fenomena terorisme dalam perjanjian umum atau aturan yang ada. Namun faktanya, tetap bahwa di bawah aturan kebiasaan internasional saat ini, terorisme yang terjadi pada masa damai dan yang bersifat internasional (yaitu tidak terbatas pada wilayah suatu negara dan menunjukkan hubungan transnasional) dapat, tergantung pada keadaan, merupakan diskrit (elemen-elemen tidak saling berhubungan). kejahatan internasional, atau kejahatan terhadap kemanusiaan.

Berbagai aksi teror yang terjadi di Indonesia cenderung dilakukan oleh pelaku yang memiliki pemahaman agama yang bersifat radikal serta disesuaikan dengan tujuan yang telah ditetapkan oleh kelompok yang menjadi kiblat atau acuan dari para pelaku tersebut. Radikalisme yang kemudian dapat berakhir pada aksi terorisme dapat disebabkan oleh banyak hal, termasuk diantaranya rasa tidak puas, merasa termarjinalkan, teralienasi, dan putus asa (Sadarusalam, Wahyudi, Mundayat, 2018).

Pemberantasan terorisme di Indonesia harus selalu di siagakan meski tak ada berita-berita akan adanya sekelompok teroris di suatu daerah tertentu atau harusnya pemberantasan terorisme itu sistem kerjanya diibaratkan seperti anti bodi yang ada di tubuh manusia. Agar supaya mempertahankan keamanan negara khususnya Indonesia jangan nanti ada kejadian baru lagi di koar-koarkan tentang pemberantasan teroris, karena yang menjadi korban selama ini adalah kebanyakan dari masyarakat sipil (Cassese, 2006).

Pemberantasan teroris di Indonesia harus di tata pengelolaannya meskipun memang tidak mudah, namun sebuah negara memang harus dan sudah menjadi kewajiban agar menjaga keamanan khususnya di Indonesia, pemerintah pun sudah 
Jurnal Pembangunan Hukum Indonesia

Volume 2, Nomor 1, Tahun 2020
Program Studi Magister Ilmu Hukum Fakultas Hukum Universitas Diponegoro melakukan berbagai cara dalam pemberantasan terorisme di Indonesia. Dinamika seputar Indonesia melawan terorisme. Hingga saat ini, informasi resmi dari pihak otoritas Indonesia mengenai kelompok teroris dan upaya melawan terorisme telah menjadi kajian paling penting dalam membentuk berbagai analisis baik di bidang akademik maupun media massa tentang masalah terorisme di tingkat nasional dan tingkat global (Choiruzzad, 2013).

Terorisme merupakan kejahatan internasional di antara 22 kejahatan yang masuk kategori tersebut (threat and use of force against internationally protected persons, taking of civilian hostages, aircraft hijacking), karena dapat mengancam perdamaian dan keamanan dunia (Muladi, 2002).

Undang-Undang Nomor 15 tahun 2003 tentang Pemberantasan Tindak Pidana Terorisme telah disahkan 25 mei 2018 yang lalu, maka sejalan dengan peraturan tersebut diharapkan pemberantasan terorisme di Indonesia akan lebih efektif kedepannya. Karena hal ini memang sangat penting dalam menjamin keamanan Indonesia maupun dari luar serta dari dalam negeri itu sendiri.

Agar Indonesia dapat melakukan pengawasan dan penjagaan yang ketat dari segi pihak yang memberantas terorisme dan setiap lapisan masyarakat serta organisasi masyarakat yang menyimpang yang ada dalam lingkup Negara Kesatuan Republik Indonesia, melihat kenyataan pelaku terorisme adalah masyarakat sipil itu sendiri.
Sehubungan dengan demikian, adapun teori yang dapat digunakan sebagai pisau analisis untuk menganalisis permasalahan ini, yaitu :

\section{a. Teori Sosio-Psikologis Narcisistik}

Isu-isu terorisme yang merebak dapat di bahas mulai dari penyebab aksi, cara berpikir, dan bertindak. Melalui analisis aspek-aspek sosiopsikologis, peneliti memperoleh cara pandang psikologis dan sosiologis kelompok-kelompok teroris internasional dan individu (Djelantik, 2010).

\section{b. Teori Pertanggungjawaban Negara}

Menurut Hegel, pertanggung jawaban (schuld) merupakan pengejawantahan dari karakter kemanusiaan (bestimmung), atau secara singkat pertanggung jawaban ialah sisi kemanusiaan kita (Alznauer, 2015). Bagi Hegel, pertanggung jawaban dimaknai sebagai suatu yang normatif, sesuatu yang obyektif, dan pelaksanaannya hanya dilakukan bilamana dalam taraf ethical evaluation (evaluasi etik) tanpa harus bertanggung jawab secara spesifik apa yang benar (rechtlich) atau secara moral (moralisch). Selain itu, menurut Hegel, suatu pihak hanya dapat dimintai pertanggung-jawabannya hanya jika ia dianggap pantas untuk dimintai bertanggung jawab terhadap apa yang dia lakukan, sejauh dia mengetahui apa yang telah dilakukan, serta mengetahui apakah yang dilakukan itu baik atau buruk.

Dari teori diatas dan model penjelasan terkait mengenai terorisme, teori yang sangat sesuai untuk menggambarkan mengenai tindakan terorisme adalah teori sosio-psikologis narcisistik. dikarenakan 
hal ini berkaitan dengan pola serta karakteristik dari pelaku teror itu sendiri dalam menjalani aksinya. Selain itu, berkaitan pula terhadap kepribadian, perilaku, serta cara berpikir para teroris terhadap lingkungan sosial.

Selanjutnya diperlukan pengawasan serta pembinaan yang lebih ekstra dari pihak-pihak pemerintah maupun dari ormas-ormas, ataupun komunitas-komunitas dan masyarakat sipil sekalipun dalam memerangi pemberantasan terorisme dari segi lingkungan sosial serta psikologis individualnya.

Bahwa dari peneliti terdahulu masih banyak menemukan permasalahan terkait dalam memerangi terorisme yang ada di indonesia. Dalam penanganan pemberantasan teroris tersebut diatas makalah ini akan mengulas tentang peran BNPT dan pihak-pihak yang berwenang dalam pemberantasan terorisme serta masyarakat, organisasi masyarakat yang ada di Indonesia.

Berdasarkan latar belakang masalah yang telah diuraikan di atas, maka penulis dapat merumuskan permasalahan sebagai berikut:

1. Bagaimana peran BNPT dalam pemberantasan terorisme di Indonesia?

2. Bagaimana peran masyarakat dan organisasi masyarakat dalam pemberantasan terorisme di Indonesia?

Penelitian ini menggunakan beberapa referensi penelitian sebelumnya yang dilakukan oleh beberapa peneliti yang membahas mengenai kejahatan terorisme. Hasil penelitian sebelumnya akan digunakan untuk mendukung penelitian ini yakni sebagai berikut:

Penelitian menurut Muhammad Ahalla Tsauro, dalam tulisannya berjudul Media Dan Terorisme Uni Eropa: Dari Teror Paris Hingga Manchester, media dan terorisme yang samasama saling mempengaruhi dan saling memanfaatkan. Studi kasus yang diambil adalah rangkaian teror di Paris (2015) dan pengeboman di Manchester (2017) karena kedua kasus ini menjadi isu global yang melibatkan jaringan pemberitaan global. Dengan menggunakan teori Efek CNN dan analisis media, penulis melihat bahwa terorisme dimanfaatkan untuk tujuan kepentingan korporasi media global dan sebaliknya, media merupakan salah satu sarana penting bagi kelompok teror untuk memperluas pengaruh dan ancamannya terhadap masyarakat global. Kemajuan teknologi informasi membuat media, sadar atau tidak, justru menjadi 'teman terbaik' bagi kelompok teroris karena medialah yang menjadi penyampai pesan utama mereka (Tsauro, 2017).

Penelitian Bahtiar Marpaung, menganalisis aspek hukum pemberantasan terorisme di Indonesia. kedua tentang perkembangan terorisme di Indonesia (Marpaung, 2007).

Penelitian menurut Barry R. Posen dalam tulisannya yang berjudul The Struggle against Terorism: Grand Strategy, Strategy and Tactics, hal yang harus dilakukan oleh suatu negara dalam upaya menanggulangi terorisme ialah dengan sebuah strategi untuk menentukan prioritas dan fokus untuk menggunakan sumber daya suatu negara baik 
sumber daya yang berupa uang, waktu, maupun modal. Termasuk juga sumber daya politik dan kekuatan militer negara tersebut (Posen, 2001).

Penelitian Handoko Sujudi, meneliti mengenai Tugas dan Kewenangan Badan Nasional Penanggulangan Terorisme Dalam Penanggulangan Terorisme di Indonesia serta Implementasi Tugas dan Kewenangan Badan Nasional Penanggulangan Terorisme (Sujudi, 2014).

Penelitian Reni Windani, membahas mengenai masalah yang dilakukan oleh Indonesia dalam memerangi terorisme. Peran Indonesia dibahas dalam lingkup internal dan eksternal (Windani, 2017).

\section{B. METODE PENELITIAN}

Penelitian merupakan suatu sarana pokok dalam pengembangan ilmu pengetahuan maupun teknologi yang bertujuan untuk mengungkapkan kebenaran secara sistematis, metodologis dan konsisten (Soekanto \& Mamudji, 2011). Metode pendekatan yang digunakan adalah metode Yuridis Normatif, dimana penelitian hukum ini memperoleh data dari data primer dan data sekunder, Spesifikasi penelitian yang digunakan dalam penelitian adalah deskriptif analisis,yakni jenis dan teknik pengumpulan data dengan literatur hukum dan kajian kepustakaan.

\section{HASIL DAN PEMBAHASAN}

1. Peran BNPT dalam pemberantasan terorisme di Indonesia

BNPT merupakan sebuah Lembaga Pemerintah Non Kementerian (LPNK) yang mempunyai tugas melaksanakan tugas pemerintahan di bidang penanggulangan terorisme. BNPT dipimpin oleh seorang kepala yang bertanggung jawab kepada Presiden melalui koordinasi Menteri Koordinator Bidang Politik, Hukum, dan Keamanan. BNPT dibentuk berdasarkan PERPRES Nomor 46 Tahun 2010 yang kemudian direvisi dengan Peraturan Presiden Nomor 12 Tahun 2012 tentang Perubahan Atas Peraturan Presiden Nomor 46 Tahun 2010 tentang Badan Nasional Penanggulangan Terorisme. BNPT sebagaimana dinyatakan dalam Pasal 2 ayat (1) Perpres Nomor 46 Tahun 2010, mempunyai tugas yakni menyusun kebijakan, strategi, dan program nasional di bidang penanggulangan terorisme; mengoordinasikan instansi pemerintah terkait dalam pelaksanaan dan melaksanakan kebijakan di bidang penanggulangan terorisme; dan melaksanakan kebijakan di bidang penanggulangan terorisme dengan membentuk satuan-satuan tugas yang terdiri dari unsur-unsur instansi pemerintah terkait sesuai dengan tugas, fungsi, dan kewenangan masing-masing (Rajab, 2016).

Mencermati perkembangan kekinian, BNPT terus menggalang berbagai elemen bangsa untuk bersama melawan radikalisme, menggalakkan kontra radikalisasi. BNPT terus bersinergi dengan lembaga pemerintah lainnya dan berbagai media untuk menyatukan dan menyamakan persepsi dalam menghadapi ancaman tersebut. Namun dalam hal inilah melihat kejadian-kejadian yang terjadi di lingkungan masyarakat, BNPT dan lembaga-lembaga 
pemerintah lainnya harus lebih mengutamakan kerja sama atau sinergi dengan Pemerintah Desa atau setidaknya menerjunkan langsung anggotanya dalam hiruk pikuk masyarakat untuk mendeteksi secara dini kegiatan atau gerakan menyimpang.

Komunikasi yang terjadi ketika seseorang mengkases media media massa adalah komunikasi yang bersifat satu arah. Hal ini mengakibatkan tidak adanya interaksi secara langsung antara komunikator dan komunikan. Informasi yang disampaikan oleh komunikator melalui media massa tersebut menjadikan pembaca dalam posisi pasif. Artinya bahwa pembaca tidak dapat menolak realitas sosial yang dibangun oleh media. Padahal, kenyataan yang dibangun oleh media belum tentu sesuai dengan realitas sosial sebenarnya (Sari, 2017).

Salah satu upaya BNPT ialah merangkul dan menggandeng generasi muda dalam memerangi radikalisme di dunia maya. BNPT sudah mengemas dan mengumpulkan sekitar 600 netizen, mulai bloger, desainer komunikasi visual, hingga ahli IT. Langkah tersebut sebagai bagian dari upaya paripurna BNPT untuk membendung dan melawan radikalisme dan terorisme di Indonesia. Meski demikian, langkah BNPT bersama jaringan FKPT di daerah-daerah memerlukan kesadaran dan gerak bersama dalam menangkal arus radikalisme yang menyasar generasi muda, antara lain, pertama, generasi muda aktif dalam kegiatan-kegiatan literasi media, literasi digital baik yang diadakan BNPT maupun lembaga non pemerintah. Tujuannya agar kalangan anak muda dapat memiliki kemampuan yang memadai dalam memilah berbagai informasi digital dan memerangi konten hoax, radikalisme, dan konten negatif lainnya. Dengan demikian, kalangan anak muda menjadi agen-agen pembaru dalam memerangi konten negatif di internet ataupun jejaring media sosial (Alius, 2017).

Melalui konektivitas internet, berbagai konten radikal seperti hakikat jihad dengan mengangkat senjata, tutorial pembuatan bom, tutorial tata cara penggunaan senjata, serta tutorial penyerangan diunggah di berbagai media sosial dan disebar secara masif, terstruktur dan sistematis (Paikah, 2019).

Radikalisme yang menyasar generasi muda hanya dapat di bendung dengan penolakan dan perlawanan dari generasi muda pula. Generasi muda kreatif, dengan bahasa dan preferensi yang sama mampu menggandeng dan merangkul yang lain untuk terhindar dari radikalisme dan terorisme. Kedua, peranan keluarga sebagai pelindung anak dari radikalisme sangat penting untuk mengawasi dan mengarahkannya.

Orang tua harus mengetahui aktivitas anak, aktif memberikan pendampingan dan pemahaman, proses pencarian jati diri dalam usia remaja sangat rentan oleh berbagai pengaruh dari luar. Meskipun mereka hanya di rumah, jendela dunia sangat terbuka melalui jejaring internet dan media sosial seperti sekarang ini.

Akses informasi ataupun interaksi komunikasi menjadi intens dengan smartphone tanpa perlu keluar rumah. Sebagai penutup, BNPT mengingatkan 
generasi muda untuk tidak menebar konten hate speech karena konten seperti itu dapat menjadi pemicu dan memupuk bibit kekerasan. BNPT mengajak seluruh anak muda bersatu padu menghadapi konten radikal yang berisi kekerasan dan terorisme.

Adapun Silber dan Bhatt, menegaskan bahwa ideologi merupakan driver yang memotivasi beberapa anak muda di Barat yang ditelitinya menjadi teroris di tempat mereka dilahirkan dan dibesarkan. Ideologi menuntun pergerakan mereka, mengidentifikasi isu-isu, menyetir rekrutmen dan sebagai landasan/dasar mereka bertindak. Ideologi telah memberikan inspirasi kepada beberapa kelompok teroris lokal seperti pengebom di Madrid pada Maret 2004, pengebom di London pada Juli 2005, kelompok teroris yang ditangkap di Australia tahun 2005 dan kelompok teroris di Toronto yang tertangkap pada Juni 2006. Hasil penelitian mereka mengungkap bahwa proses radikalisasi kelompok teroris yang ditelitinya melalui empat fase yaitu: PreRadicalization; Self-Identification; Indoctrination; dan J ihadization. Lebih lanjut, Silber menyatakan bahwa setiap fase adalah unik dan memiliki ciri tersendiri (Isnanto, 2015).

\section{a. Visi dan Misi Badan Nasional Penanggulangan Terorisme}

Visi BNPT adalah untuk mewujudkan penanggulangan terorisme dan radikalisme melalui upaya sinergi institusi pemerintah dan masyarakat yang meliputi pencegahan, perlindungan, deradikalisasi dan penindakan, serta peningkatan kewaspadaan nasional dan kerja sama internasional untuk menjamin terpeliharanya keamanan nasional (Bakti, 2014).

Berdasarkan visi BNPT di atas, dijabarkan juga misi BNPT sebagai langkah-langkah BNPT dalam melakukan program untuk mencapai visi tersebut. Ada 5 poin misi BNPT yaitu:

1. Melakukan pencegahan terjadinya aksi terorisme, meningkatkan kewaspadaan dan memberikan perlindungan terhadap objek-objek vital yang potensial menjadi target serangan terorisme.

2. Melakukan deradikalisasi dan melawan propaganda ideologi radikal.

3. Melakukan penindakan aksi terorisme melalui penggalangan intelijen dan surveillance, dan penegakan hukum melalui kordinasi dan kerjasama dengan institusi terkait, masyarakat, dan seluruh komponen bangsa.

4. Melaksanakan pembinaan kemampuan dan kesiapsiagaan nasional terhadap ancaman aksi terorisme.

5. Melaksanakan kerjasama internasional dalam penanggulangan terorisme.

Berikut pasal-pasal yang mengatur peran BNPT dalam penanggulangan terorisme (RUU No 15 Tahun 2003):

- Pasal 43E

1. Badan yang menyelenggarakan urusan di bidang penanggulangan terorisme yang selanjutnya disebut Badan Nasional Penanggulangan Terorisme, berada di bawah dan bertanggung jawab kepada Presiden. 
2. Badan Nasional Penanggulangan Terorisme menjadi pusat analisis dan pengendalian krisis yang berfungsi sebagai fasilitas bagi Presiden untuk menetapkan kebijakan dan langkahlangkah penanganan krisis, termasuk pengerahan sumber daya dalam menangani terorisme.

3. Badan Nasional Penanggulangan Terorisme berkedudukan di ibukota Negara Republik Indonesia.

\section{- Pasal 43F}

Badan Nasional Penanggulangan Terorisme berfungsi:

1. menyusun dan menetapkan kebijakan, strategi, dan program nasional di bidang penanggulangan terorisme;

2. menyelenggarakan koordinasi kebijakan, strategi, dan program nasional di bidang penanggulangan terorisme; dan

3. melaksanakan kesiapsiagaan nasional, kontra radikalisasi, dan deradikalisasi.

\section{- Pasal 43G}

Melaksanakan fungsi sebagaimana dimaksud dalam Pasal 43F, Badan Nasional Penanggulangan Terorisme bertugas:

1. merumuskan, mengoordinasikan, dan melaksanakan kebijakan, strategi, dan program nasional penanggulangan terorisme di bidang kesiapsiagaan nasional, kontra radikalisasi, dan deradikalisasi;

2. mengoordinasikan antar penegak hukum dalam penanggulangan terorisme;
3. mengoordinasikan program pemulihan korban; dan

4. merumuskan, mengoordinasikan, dan melaksanakan kebijakan, strategi, dan program nasional penanggulangan terorisme di bidang kerja sama internasional.

\section{- Pasal $43 \mathrm{H}$}

Ketentuan mengenai susunan organisasi Badan Nasional Penanggulangan Terorisme diatur dengan Peraturan Presiden.

Jika kita melihat dari visi misi BNPT diatas sudah sangat bagus, namun dalam kenyataan yang terjadi di dalam lingkungan Indonesia belum terlalu maksimal pelaksanaannya karena masih adanya aksi terorisme yang lolos seperti di Surabaya bulan 5 2018 yang lalu, peran BNPT memang masih minim pencegahan dan deteksi dini yang yang diupayakan sehingga masih banyak yang bisa lolos dari pantauan.

Hal inilah juga yang masih kurang dalam pelaksanaan pemberantasan terorisme di Indonesia. dimana masyarakat dan komunitas belum terlalu dimaksimalkan partisipasinya dalam pemberantasan terorisme, buktinya selama ini nanti setelah terjadi baru media dan pihak yang berwenang menanyakan pelaku teror tersebut terhadap masyarakat atau tetangga si pelaku teror dan mencari tahu asal usul komunitas si pelaku teror.

b. Berbagai upaya kebijakan pencegahan telah dilakukan oleh BNPT diantaranya (Sihombing, \& Soeriatmadja, 2009) : 


\section{(1). Peran Intelijen}

Mengaktifkan peran intelijen yang aktif, walaupun upaya ini terkendala oleh masih kuatnya resistensi terhadap peranan intelijen akibat trauma masa lalu oleh kelompok-kelompok tertentu. Sehingga aparat keamanan selalu kecolongan dan menimbulkan kesan hanya bertindak reaktif dan inisiatif lebih banyak di tangan teroris.

Secara umum fungsi sebuah organisasi intelijen negara adalah mengamankan kepentingan nasional (Soegirman, 2012). Dalam aplikasi sistem pemerintah Indonesia peranan intelijen adalah memberikan peringatan (early detection and early warning system) tentang hal-hal yang berkaitan dengan ancaman terhadap negara dari dalam maupun dari luar.

Secara yuridis maka peran intelijen jika diterjemahkan dari tujuan Intelijen Negara yang tertulis dalam UU Nomor 17 tahun 2011 tentang Intelijen Negara Pasal 5 disebutkan bahwa: Tujuan Intelijen Negara adalah mendeteksi, mengidentifikasi, menilai, menganalisis, menafsirkan, dan menyajikan Intelijen dalam rangka memberikan peringatan dini untuk mengantisipasi berbagai kemungkinan bentuk dan sifat ancaman yang potensial dan nyata terhadap keselamatan dan eksistensi bangsa dan negara serta peluang yang ada bagi kepentingan dan keamanan nasional.

(2). Hukum

Membuka wacana dalam rangka membangun perangkat hukum yang efektif, karena selama ini kebijakan pemerintah hanya fokus pada upaya penegakan hukum, sementara pasal hukum yang digunakan untuk mengadili sangat lemah dan dasar atau payung hukum yang digunakan sangat lemah. Upaya penegakan hukum selama ini hanya mampu menjerat pada tataran operator atau pelaku di lapangan, sementara master mind, provokator dan spiritual leader belum terjangkau. Selain itu regulasi yang ada belum mampu mempersempit ruang gerak aktivitas terorisme.

Agar supaya mencapai sebuah tujuan negara yang aman dan damai BNPT mempunyai sebuah strategi pencegahan terorisme. Strategi pencegahan terorisme merupakan serangkaian pekerjaan dan cara bertindak dalam melakukan pencegahan terorisme itu sendiri. Kebijakan dan strategi pencegahan terorisme sengaja dirancang untuk mendeteksi dan mencegah berbagai macam aksi terorisme di indonesia.

Program Pencegahan yang dilaksanakan oleh BNPT terdiri dari dua strategi. Pertama, strategi deradikalisasi yang ditunjukan terhadap kelompok inti dan militan terorisme dengan melaksanakan kegiatan penangkalan, rehabilitasi, reduksi, dan resiosialisasi.

Kedua, strategi kontra radikalisasi yang ditujukan terhadap kelompok pendukung, simpatisan, dan masyarakat dengan melaksanakan kegiatan pencegahan yang meliputi kegiatan pengawasan terhadap orang, senjata api, dan kegiatan kontra propaganda, kegiatan kewaspadaan serta kegiatan perlindungan terhadap objek vital, trasnportasi, VVIP serta lingkungan dan fasilitas publik. 
Dalam melaksanakan tugas dan fungsi, di lingkungan BNPT dibentuk Satuan-Satuan Tugas yang selanjutnya disebut Satgas yang terdiri dari unsur-unsur instansi terkait (PERPRES No. 46 Tahun 2010). yang salah satunya dari Mabes Polri membentuk Detasemen Khusus 88/Anti Teror yang bertugas menghentikan aksi teror dan mengungkap jaringan teroris melalui upaya penegakan hukum.

Dasar hukum pembentukan Densus 88 yaitu SK Kapolri No. 30/VI/2003 Tertanggal 20 Juni 2003, hal ini sekaligus tindak lanjut merealisasikan UU No.15 Tahun 2003 tentang Penetapan PERPU No. 1 Tahun 2002 tentang Pemberantasan Tindak Pidana Terorisme.

Seperti Densus 88 sendiri sebenarnya sudah baik dalam pelaksanaan tugasnya selama ini sudah beberapa kelompok terorisme yang tertangkap oleh pasukan pemberantas aksi terorisme tersebut.

Namun saat ini kalangan radikal-terorisme melihat perilaku masyarakat dan negara sebagai gambaran nature of people yang buruk, jahat, diskriminatif, korup, thogut dan tidak Islami. Oleh sebab itu, pandangan nature of people yang buruk akan berubah jika para aparat penegak hukum, pejabat negara dan masyarakat menciptakan kehidupan sosial yang toleran, peduli dan berkeadilan sosial (Zuhri, 2017).

Tetapi perlunya pemerataan dari segala sisi mulai dari kesejahteraan masyarakat serta keadilan yang paling mendasar secara komprehensif, untuk meminimalisir terjerumusnya warga dalam hal-hal yang mengarah ke kelompok-kelompok atau gerakan-gerakan yang mengarah ke radikalisme.

\section{Peran Masyarakat Dan Organisasi Masyarakat Dalam Pemberantasan Terorisme Yang Ada Di Indonesia}

\section{a. Peran Masyarakat}

Pemberantasan terorisme pihak media saja tidak cukup untuk menyeimbangkan dan memurnikan media dari paham radikalisme. Sinergitas peran dengan berbagai pihak juga sangat diperlukan, termasuk tokoh masyarakat yang ada di setiap daerah atau Kepala daerah pun harusnya lebih aktif, tokoh politik, dan tokoh ulama.

Basis masyarakat yang harus dibangun adalah gerakan moral untuk melawan terorisme ataupun ideologi radikal. Gerakan moral masyarakat harus membuat para napiter tidak mengalami keterasingan sehingga kembali dapat berperilaku sesuai dengan orang-orang di sekitarnya (Indrawan, \& Aji, 2019).

Peran ulama sangat dibutuhkan dalam pemberantasan terorisme, yakni untuk menghambat arus radikalisme agar tidak terlalu deras mengalir ke media, seperti contoh melalui fatwa kolektif yang dikeluarkan oleh para tokoh agama. Namun, upaya para ulama tidak akan berdampak signifikan tanpa bantuan media, karena tanpa media fatwa dan pemikiran moderat dan toleran dimaksud akan terisolasi dan terbatas. Media sebagai alat penyampaian pesan bagi para ulama dalam menyebarkan dan menyampaikan fatwa-fatwa yang ada. 
Jurnal Pembangunan Hukum Indonesia

Volume 2, Nomor 1, Tahun 2020
Program Studi Magister Ilmu Hukum Fakultas Hukum Universitas Diponegoro
Media dimaksud tidak hanya terbatas pada media online, televisi, atau radio saja, akan tetapi juga dengan media cetak, seperti buku dan lain-lain. Maka dari itu masyarakat harus dirangkul oleh pemerintah ataupun tokoh ulama untuk ikut serta dalam dan memberikan arahan kepada masyarakat lebih sistematis tentang radikalisme untuk pemberantasan terorisme sebab bukan tidak mungkin semua lapisan masyarakat yang ada di Indonesia mengerti dan paham akan hal tersebut.

Olehnya pemerintah dan khususnya BNPT bisa merangkul masyarakat, organisasi, komunitas yang ada di Indonesia, dalam pengarahan dan menjadikan sumber informasi akan adanya sekumpulan komunitas yang agak menyimpang dilingkungan ditengah masyarakat. Lingkungan sosial yang acuh tak acuh terhadap kegiatan masyarakat bisa dimanfaatkan oleh kelompok teroris untuk menyemai dan menumbuh suburkan gerakannya, namun lingkungan sosial juga bisa mempunyai peran ganda.

Dikarenakan di satu sisi lingkungan bisa memberikan sumbangsih bagi proses ideologisasi dan pembentukan jaringan terorisme, khususnya lingkungan masyarakat yang cenderung tidak peduli atas apa yang terjadi di sekitarnya. Di sisi lain, masyarakat dan lingkungan juga bisa berperan dalam menghambat, mencegah, dan mengungkap persoalan terorisme. Itu sebabnya dibutuhkan adanya langkah strategis agar peran masyarakat dan lingkungan sosial bisa optimal dalam upaya penanggulangan dan pencegahan terorisme.
Setidaknya karena masyarakat lebih mengetahui tentang kondisi lingkungannya dibanding pihak lain, termasuk dalam mengenali pendatang baru ataupun perubahan yang mengarah pada radikalisasi dari orang/pihak tertentu. Misalnya dengan memaksimalkan peran lingkungan sosial yang paling kecil seperti komunitas pemuda di setiap daerah atau $\mathrm{RT} / \mathrm{RW}$.

Sebagai ujung tombak aparat negara, pemuda Indonesia atau RT/RW bisa berperan optimal untuk mengontrol setiap aktivitas di lingkungan masyarakat di lingkungannya. Melalui peran lembaga di lingkungannya, ancaman terorisme bisa dicegah secara dini, bahkan potensinya sekalipun. Hampir bisa dipastikan, kehadiran jaringan/anggota terorisme yang bersembunyi di tengah-tengah masyarakat membawa tanda-tanda radikalisasi tertentu. Dengan demikian, sedikit banyaknya faham dan ideologi lain tidak memiliki tempat sehingga tidak mampu berkembang di Indonesia. Sebab masalah terorisme bukanlah masalah kelompok tapi persoalan bangsa yang harus diperangi oleh seluruh elemen masyarakat dan punya komitmen bersama.

\section{b. Peran Organisasi Masyarakat}

Organisasi masyarakat yang saya maksud di sini adalah kelompok masyarakat yang bukan merupakan bagian dari negara (the state) dan juga bukan bagian dari lembaga bisnis dan ekonomi (the economical). Contoh dari organisasi masyarakat adalah ormas semacam NU, Muhammadiyah di samping juga LSM-LSM. Pada umumnya, Ormasormas besar Islam seperti NU dan Muhammadiyah 
memiliki pandangan yang sama soal dampak yang diakibatkan oleh ekstrimisme keagamaan. Sejalan dengan NU dan Muhammadiyah adalah MUI yang sudah mengeluarkan fatwa tentang keharaman tindakan terorisme.

Pentingnya kajian mengenai Organisasi Islam Transnasional cukup beralasan karena gerakan keagaamaan ini memberi fenomena baru dalam kehidupan keagamaan di tengah-tengah masyarakat Indonesia saat ini. Gerakan tersebut menunjukkan lingkup yang tidak hanya terbatas pada wilayah nasional atau lokal seperti halnya organisasi kemasyarakat (ormas) Islam seperti Muhammadiyah dan Nahdlatul Ulama (NU) yang menganut paham Islam moderat, namun gerakan dan aktifitas dari kelompok ini telah melampaui sekat-sekat teritorial negara-bangsa (nation-state).

Ideologi dari Organisasi Islam Transnasional yang cenderung fundamentalis, oleh BNPT dimasukkan ke dalam kelompok radikal yang ada di Indonesia dan dianggap mengancam keutuhan NKRI karena sebagian dari mereka ingin merubah sistem pemerintahan yang ada saat ini (Hermastuti, 2016).

Berdasarkan paparan di atas, dari segi ekstremisme keagamaan yang berdampak nyata seperti terorisme, sikap lembaga keagamaan sangat jelas, namun untuk ekstremisme keagamaan par excellence, maka masyarakat sipil masih bersikap ambigu. Misalnya, pada satu sisi, mereka mengutuk pelbagai bentuk kekerasan bermotif agama seperti terorisme dan lainnya, namun pada sisi yang lain mereka tidak punya cara pandang dan sikap yang jelas pada wacana keagamaan yang menganjurkan kebencian.

Atas nama penghinaan keyakinan, fatwa-fatwa keagamaan yang memicu pada sikap ekstremisme dan bahkan tindakan berbasis agama tetap berjalan. Misalnya, NU, Muhammadiyah dan MUI mengutuk terorisme namun mereka tidak berbicara apa-apa soal kekerasan yang menimpa kaum Syiah dan Ahmadiyah. Sampai sekarang, kita tidak bisa menyelesaikan ekstremisme keagamaan yang terjadi di internal umat Islam sendiri. Suasana sekarang adalah suasana penuh propaganda dan setiap upaya yang diupayakan untuk mencari jalan keluar distigmatisasi dengan hal-hal yang buruk (Asrori, 2015).

Melihat uraian diatas di Indonesia sendiri memang belum terlalu bersinergi antara ormasormas satu dengan yang lainnya maupun itu organisasi kecil di lingkungan masyarakat sekalipun, maka pemerintah harusnya lebih fokus merangkul dan mengarahkan melalui pelatihan tentang gerakan yang radikal kepada ormas-ormas yang kecil hingga yang besar agar terjadi komunikasi yang baik antara ormas yang berbeda wilayah sekalipun dalam pemberantasan terorisme di Indonesia. Namun kita bisa melihat sekarang disahkannya Perpu Ormas dan banyaknya ormas yang dileburkan atau dibubarkan oleh pemerintah, sebenarnya hal tersebut juga baik dan pemerintah ingin membatasi ormasormas yang radikal.

Namun disisi lain ormas yang dileburkan atau dibubarkan bisa saja akan merasa adanya kebencian 
karena dalam suatu ormas semua anggotanya tidak berpikiran sama. Jadi ini juga bisa menjadi kekhawatiran bila salah satu atau lebih dari dua anggota ormas tersebut berpikiran seperti ini. Hal Ini juga bisa menjadi salah satu jalan untuk masyarakat dalam berfikir serta bertindak radikal, harusnya pemerintah merangkul, memberikan arahan kembali kepada anggota ormas tersebut yang dibubarkan yang juga adalah masyarakat Indonesia itu sendiri untuk mencegah dan membendung pemberantasan terorisme di Indonesia.

Memang harusnya sudah menjadi tugas pemerintah serta semua lapisan untuk kembali menyadarkan masyarakat dan pemuda-pemuda yang demikian bersemangat, agar kembali memahami pengertian baik dan buruk, pengertian haram dan halal serta pengertian jihad dan mati syahid.

Di sisi inilah masyarakat dan pemuda banyak digelincirkan. Umumnya serangan teror hanya ramai dibicarakan saat kejadian, dan biasanya setelah beberapa lama akan dilupakan. Perang dengan terorisme adalah perang yang sangat serius. Strategi budaya harus terus dilakukan pemerintah. Akibat kurangnya perhatian ini, sulit bagi warga untuk menilai sejauh mana keberhasilan ataupun kegagalan pemerintah dalam memberantas radikalisme dan kekerasan yang menyertainya.

\section{SIMPULAN}

Untuk melaksanakan peran, serta tugas dan fungsi, di lingkungan BNPT dibentuk Satuan TugasSatuan Tugas yang selanjutnya disebut Satgas yang terdiri dari unsur-unsur instansi terkait, yang salah satunya dari Polri. Mabes Polri membentuk Detasemen Khusus 88/Anti Teror yang bertugas menghentikan aksi teror dan mengungkap jaringan teroris melalui upaya penegakan hukum dan peran intelijen juga sangatlah penting begitupun dengan hukum perannya sangat berperan Untuk mencapai sebuah tujuan negara yang aman dan damai BNPT mempunyai sebuah strategi pencegahan terorisme. Strategi pencegahan terorisme merupakan serangkaian pekerjaan dan cara bertindak dalam melakukan pencegahan terorisme itu sendiri. Namun sebaiknya Kebijakan dan strategi pencegahan terorisme harus dirancang sesempurna mungkin untuk mencegah berbagai macam aksi terorisme di indonesia. Serta ada enam prinsip-prinsip yang harus dikedepankan oleh BNPT yaitu dari segi supremasi, indiskriminasi, independensi, koordinasi, demokrasi dan partisipasi yang keenam inilah harus jadi sebuah acuan. Diantara keenam itu hanya satu yang kurang dalam pelaksanaannya yaitu prinsip partisipasi dimana kita melihat warga negara Indonesia secara keseluruhan banyak yang masih awam akan pemberantasan terorisme, serta komunitas atau ormas yang kecil yang berada di daerah-daerah dirangkul dan diarahkan oleh BNPT. Maka dari itu BNPT harusnya lebih menekankan dan mengajak dan memberikan penyuluhan atau pendidikan kepada masyarakat, komunitas atau ormas-ormas yang ada di daerah mulai dari berbagai elemen tentang pentingnya akan pemberantasan terorisme. 
Jurnal Pembangunan Hukum Indonesia

Volume 2, Nomor 1, Tahun 2020
Program Studi Magister Ilmu Hukum Fakultas Hukum Universitas Diponegoro
Dalam upaya menangani terorisme secara efektif diperlukan peran serta masyarakat yang secara aktif ikut berpartisipasi dalam melakukan kegiatan pemberantasan terorisme. Pelaksanaan dilakukan oleh setiap negara yang memiliki potensi ancaman terorisme dengan menetapkan strategi dan kebijakan yang bertujuan untuk melakukan penyangkalan akses bagi kelompok teroris terhadap tujuan, target, dan dampak negatif yang bersifat massal yang menjadi tujuan dari pelaksanaan aksi/kegiatan yang mereka lakukan. Masyarakat, Maka dari itu masyarakat harus dirangkul oleh pemerintah ataupun tokoh ulama untuk ikut serta dalam dan memberikan arahan kepada masyarakat lebih sistematis tentang radikalisme untuk pemberantasan terorisme sebab bukan tidak mungkin semua lapisan masyarakat yang ada di Indonesia mengerti dan paham akan hal tersebut. Olehnya pemerintah dan khususnya BNPT bisa merangkul masyarakat, organisasi, komunitas yang ada di Indonesia, dalam pengarahan dan menjadikan sumber informasi akan adanya sekumpulan komunitas yang agak menyimpang dilingkungan ditengah masyarakat. selain dapat membantu tercapainya tujuan. Di Indonesia sendiri memang belum terlalu bersinergi antara ormas-ormas satu dengan yang lainnya maupun itu organisasi kecil di lingkungan masyarakat sekalipun, maka pemerintah harusnya lebih fokus merangkul dan mengarahkan melalui pelatihan tentang gerakan yang radikal kepada ormas-ormas yang kecil hingga yang besar agar terjadi komunikasi yang baik antara ormas yang berbeda wilayah sekalipun dalam pemberantasan terorisme di Indonesia. Dengan demikian, sedikit banyaknya paham dan ideologi lain tidak memiliki tempat sehingga tidak mampu berkembang di Indonesia. Sebab masalah terorisme bukanlah masalah kelompok tapi persoalan bangsa yang harus diperangi oleh seluruh elemen masyarakat dan punya komitmen bersama.

\section{DAFTAR PUSTAKA}

\section{BUKU}

Alznauer, M. (2015). Hegel's Theory of Responsibility. Cambridge: Cambridge University Press.

Sihombing, Ivan TH., \& Soeriatmadja, Rhousdy. (2009). Kiprah DKPT Dalam Situasi Kontroversi Dan Keterbatasan. Jakarta: S.I.

Djelantik, S. (2010). Terorisme Tinjauan Psiko-Politis, Peran Media, Kemiskinan, dan Keamanan Nasional. Jakarta : Yayasan Obor Indonesia.

Hikam, Muhammad A.S. (2016). Deradikalisasi: Peran Masyarakat Sipil Indonesia Membendung Radikalisme. Jakarta: PT Kompas Media Nusantara.

Bakti, Agus S. (2014). Darurat Teorisme: Kebijakan, Pencegahan,Perlindungan,dan Deradikalisasi. Jakarta: Daulat Press.

Soekanto, Soerjono., \& Mamudji, Sri. (2011). Penelitian Hukum Normatif, Cetakan ke-13, Jakarta: PT. RajaGrafindo Persada.

Soegirman, S. (2012). Intelijen Profesi Unik OrangOrang Aneh. Jakarta: Media Bangsa. 
Jurnal Pembangunan Hukum Indonesia

Volume 2, Nomor 1, Tahun 2020
Program Studi Magister Ilmu Hukum Fakultas Hukum Universitas Diponegoro

\section{JURNAL}

Sadarusalam., Bambang Wiji Asmoro., Wahyudi, Bambang., \& Mundayat, Aris Arif. (2018).

Strategi Kontra Propaganda Badan Nasional

Penanggulangan Terorisme Dalam

Menanggulangi Perkembangan Radikalisme

Kontemporer di Indonesia. Jurnal

Peperangan Asimetrik, Vol.4, (No. 3), pp.4160.

Asrori, A. (2015). Radikalisme di Indonesia: Antara Historisitas dan Antropisitas. Kalam: Jurnal Studi Agama dan Pemikiran Islam, Vol. 9, (No.2, Desember), pp.263-264.

Cassese, A. (2006). The Multifaceted Criminal Notion of Terrorism in International Law. J ournal of International Criminal J ustice, Vol.4, Issue 5, (November), pp.933-958.

Choiruzzad, Shofwan Al Banna. (2013). Within a Thick Mist: Conspiracy Theories and Counter Terrorism in Indonesia. International J ournal of Social Inquiry, Vol.6, (No. 2), pp.96-116.

Sari, Benedicta Dian Ariska C. (2017). Media Literasi

Dalam Kontra Propaganda Radikalisme dan Terorisme Melalui Media Internet. Jurnal Peperangan Asimetrik, Vol.3, (No. 1), pp.1531.

Hermastuti, Mirza D. (2016). Respon Organisasi Islam Transnasional di Indonesia Terhadap Program Deradikalisasi Badan Nasional Penanggulangan Terorisme (BNPT). J ournal of International Relations, Vol.2, (No.1), pp.122-130.
Isnanto, Samto H. (2015). Berbagai Masalah dan Tantangan Radikalisasi dan Deradikalisasi Terorisme di Indonesia. J urnal Pertahanan \& Bela Negara, Vol.5, (No. 2 Agustus), pp.225244.

Indrawan, Jerry., \& Aji, M. Prakoso. (2019). Efektifitas Program Deradikalisasi Badan Nasional Penanggulangan Terorisme Terhadap Narapidana Terorisme di Indonesia. J urnal Pertahanan dan Bela Negara, Vol.9, (No. 2 Agustus), pp.1-20.

Marpaung, B. (2007). Aspek Hukum Pemberantasan Terorisme di Indonesia, Jurnal Equality, Vol.12 (No. 2 Agustus), pp.120-130.

Muladi. (2002). Hakekat Terorisme dan Beberapa Prinsip Pengaturan Dalam Kriminalisasi. Jurnal Kriminologi Indonesia, Vol.2 (No. III Desember), p.3.

Paikah, N. (2019). Kedudukan dan Fungsi Badan Nasional Penanggulangan Terorisme (BNPT) Dalam Pemberantasan Terorisme di Indonesia, Jurnal Al-Adalah. J urnal Hukum dan Politik Islam, Vol.4, (No. 1, januari), pp.1-20.

Posen, Barry R. (2001). The Struggle against Terorism: Grand Strategy, Strategy and Tactics. International Security, Vol 26, (No. 3), pp.39-55.

Rajab, A. (2016). Urgensi Penguatan BNPT Dalam Rangka Menjaga Keamanan dan Kedaulatan Negara. Jurnal RECHTSVINDING; Media 
Jurnal Pembangunan Hukum Indonesia

Volume 2, Nomor 1, Tahun 2020

Pembinaan Hukum Nasional, Vol.5, (No. 1 , April), pp.1-15.

Sujudi, H. (2014). Implementasi Tugas dan Kewenangan Badan Nasional Penanggulangan Terorisme di Indonesia. J urnal Lex et Societatis, Vol.II, (No. 8 SepNov), pp.22-31.

Windani, R. (2017). Peran Indonesia dalam Memerangi Terorisme. Jurnal IImu Sosial, Vol.16, (No. 2. Edisi Juli-Desember), pp.135152.

Zuhri, S. (2017). Kebijakan Deradikalisasi Terorisme oleh BNPT : Perspektif Spektrum Politik. J urnal Ilmu Kepolisian, edisi 089 (AgustusOktober), pp.75-81.

Tsauro, Muhammad A. (2017). Media dan Teorisme di Uni Eropa : dari Teror Paris Hingga Bom Manchester. Jurnal ICMES, Vol.1, (No.2), pp.146-165.

\section{PERATURAN DAN PERUNDANG-UNDANGAN}

Peraturan Presiden Nomor 46 Tahun 2010 tentang Badan Nasional Penanggulangan Terorisme. Undang-Undang Nomor 2 Tahun 2002, Tentang Kepolisian Negara Republik Indonesia.

RUU Nomor 15 Tahun 2003 tentang Pemberantasan Tindak Pidana Terorisme.

\section{SUMBER ONLINE}

Alius, S. (2017). Terorisme Menyasar Generasi Muda. Retrieved from
Program Studi Magister Ilmu Hukum Fakultas Hukum Universitas Diponegoro

http://mediaindonesia.com/read/detail/10338 5-terorisme-menyasar-generasi-muda. 